\title{
Effects of Reactive Air Brazing Parameters on the Interfacial Microstructure and Shear Strength of GDC-LSM/Crofer 22 APU Joints
}

\author{
Kati Raju (1)*,; Seyoung Kim*, Young-Hoon Seong*, and Dang-Hyok Yoon $(\mathbb{D} * * *$ \\ ${ }^{*}$ Energy Efficiency and Materials Research Division, Korea Institute of Energy Research, Daejeon 34129, Korea \\ ${ }^{* *}$ School of Materials Science and Engineering, Yeungnam University, Gyeongsan 38541, Korea
}

(Received June 21, 2019; Revised July 12, 2019; Accepted July 12, 2019)

\begin{abstract}
In this paper, the joining characteristics of GDC-LSM ceramics with Crofer 22 APU metal alloys was investigated at different brazing temperatures and holding times by reactive air brazing. Brazing was performed using $\mathrm{Ag}-10 \mathrm{wt} \% \mathrm{CuO}$ filler, at three different temperatures $\left(1000,1050\right.$, and $1100^{\circ} \mathrm{C}$ for 30 minutes) as well as for three different holding times $(10,30$, and 60 minutes at $1050^{\circ} \mathrm{C}$ ). The interfacial microstructures were examined by scanning electron microscopy and the joining strengths were assessed by measuring shear strengths at room temperature. The results show that with increasing brazing temperature and holding time, joint microstructure changed obviously and shear strength was decreased. Shear strength varied from a maximum of $100 \pm 6 \mathrm{MPa}$ to a minimum of $18 \pm 5 \mathrm{MPa}$, depending on the brazing conditions. These changes were attributed to an increase in the thickness of the oxide layer at the filler/metal alloy interface.
\end{abstract}

Key words : GDC-LSM ceramics, Crofer 22 APU, Reactive air brazing, Shear strength

\section{Introduction}

$\mathbf{R}_{\mathrm{p}}^{\mathrm{e}}$ eactive air brazing (RAB) is a simple, inexpensive and promising technique for joining dissimilar materials, which can be performed in air using a furnace without the need for any special apparatus. Earlier studies reported the effectiveness of RAB for joining a variety of ceramics and metal alloys using $\mathrm{Ag}-\mathrm{CuO}$ fillers. ${ }^{1-10)}$ The $\mathrm{Ag}-\mathrm{CuO}$ phase diagram has eutectic and monotectic points at 932 and $964^{\circ} \mathrm{C}$, respectively. ${ }^{2)}$ Hence, RAB is generally performed for several minutes at temperatures higher than the melting temperature of the $\mathrm{Ag}-\mathrm{CuO}$ filler. However, joint strength and morphology will vary with changing brazing parameters, which mainly include brazing temperature and holding time. ${ }^{5,11-14)}$ Different researchers have used different brazing protocols for joining various materials. ${ }^{6,15-20)}$ For instance, LSCF/FeCrAlloy and BCFZ/FeCrAlloy joints were brazed at temperatures of $1020-1100^{\circ} \mathrm{C}$ for 30 to $180 \mathrm{~min}$ utes by Chen et al. ${ }^{6)}$ BSCF/AISI 314 joints were successfully brazed for 20 minutes at a brazing temperature of $955^{\circ} \mathrm{C}^{15)}$ YSZ/AISI 314 and BSCF/Crofer $22 \mathrm{H}$ joints were brazed at

\footnotetext{
Corresponding author : Kati Raju

E-mail : katiraju@gmail.com

Tel : +82-42-860-3471 Fax : +82-42-860-3133

ORCID

https://orcid.org/0000-0002-0853-5574

ॠCorresponding author : Dang-Hyok Yoon

E-mail : dhyoon@ynu.ac.kr

Tel : +82-53-810-2561 Fax : +82-53-810-4628

ORCID

https://orcid.org/0000-0002-6539-5096
}

$970^{\circ} \mathrm{C}$ for 20 minutes using Ag3Cu filler. ${ }^{16)}$ TSZ3Y/Crofer 22 $\mathrm{H}$ joints were brazed for only 5 minutes at a fixed temperature of $1000^{\circ} \mathrm{C}{ }^{17)}$ Zirconia-toughened alumina was brazed with different Ni-based alloys at $1100^{\circ} \mathrm{C}$ for 30 minutes. ${ }^{18)}$

$\mathrm{Ce}_{0.9} \mathrm{Gd}_{0.1} \mathrm{O}_{2-\delta}-\mathrm{La}_{0.7} \mathrm{Sr}_{0.3} \mathrm{MnO}_{3 \pm \delta}$ (GDC-LSM) ceramics are recognized as one of the most promising oxygen transport membrane (OTM) materials. ${ }^{21,22)}$ Crofer 22 APU, a ferritic stainless steel, is one of the most commercially available and inexpensive metal alloys, which has been developed for use at high temperatures. Due to the high Cr content (22$24 \mathrm{wt} \%$ ), this alloy exhibits superior strength and oxidation resistance at high temperatures. Crofer 22 APU has been successfully brazed using $\mathrm{Ag}-\mathrm{CuO}$ for solid oxide fuel cells and OTM applications. ${ }^{7,9,10,23)}$ In our previous studies, ${ }^{7,9,10)}$ we reported on the successful brazing of GDC-LSCF and GDC-LSM ceramics with Crofer 22 APU at a fixed temperature of $1050^{\circ} \mathrm{C}$ for 30 minutes.

In order to obtain superior joining properties in RAB, it is necessary to use optimal brazing temperatures and times. Exploring the optimal brazing parameters may provide guidance for practical applications. So far, no studies have suggested generalized optimal brazing parameters, since the brazing properties are strongly dependent on the brazed materials. Indeed, there are very few studies on the effects of varying brazing temperature and holding time on interfacial microstructures and mechanical properties. In this paper, we evaluate optimal brazing temperature and holding time by examining the interfacial microstructure and shear strength of GDC-LSM/Crofer 22 APU joints. 


\section{Experimental Procedure}

Five different GDC-LSM/Crofer 22 APU joints were prepared by using different brazing parameters, as shown in Table 1. Details about the brazing parameters, fabrication of ceramics and the joining procedure are reported in our recent publication. ${ }^{9}$ ) The joints were brazed in air using a box furnace at different temperatures (1000, 1050, and $1100^{\circ} \mathrm{C}$ for 30 minutes) and for different times $(10,30$, and 60 minutes at $1050^{\circ} \mathrm{C}$ ) with a heating rate of $5^{\circ} \mathrm{C} /$ minute.

Table 1. Brazing Parameters Used for GDC-LSM/Crofer 22 APU Joints and their Shear Strengths

\begin{tabular}{cccc}
\hline $\begin{array}{c}\text { Sample } \\
\text { no }\end{array}$ & $\begin{array}{c}\text { Brazing } \\
\text { temperature }\left({ }^{\circ} \mathrm{C}\right)\end{array}$ & $\begin{array}{c}\text { Holding time } \\
(\mathrm{min} .)\end{array}$ & $\begin{array}{c}\text { Shear strength } \\
(\mathrm{MPa})\end{array}$ \\
\hline 1 & 1000 & 30 & $91 \pm 8$ \\
2 & 1050 & 30 & $89 \pm 9$ \\
3 & 1100 & 30 & $18 \pm 5$ \\
4 & 1050 & 10 & $100 \pm 6$ \\
5 & 1050 & 60 & $53 \pm 8$ \\
\hline
\end{tabular}

Two types of joint structures were prepared: Interfacial microstructures were observed on a whole lap-joint and shear strength measurements were carried out using an offset lap-joint. Scanning electron microscopy (SEM: S-4800, Hitachi) was used to characterize the microstructure of joining interfaces and fractured surfaces. By using a universal testing machine (MTS Landmark, USA), the shear strength of the joints was evaluated at room temperature at a head speed of $0.05 \mathrm{~mm} /$ minute according to ASTM D905. ${ }^{24)}$ An average of 3-5 joints are reported here for shear strength.

\section{Results and Discussion}

Cross-sectional SEM micrographs of GDC-LSM/Crofer 22 APU joints brazed at different brazing temperatures of 1000,1050 , and $1100^{\circ} \mathrm{C}$ for 30 minutes are compared in Fig. 1. The overview of joints brazed at $1000^{\circ} \mathrm{C}$ along with the ceramic/filler and filler/metal interfaces at higher magnifications are presented in Fig. 1(a), which shows that the joint is in complete fusion, without any defects. Moreover, both interfaces are free of cracks and sound joining was

(a) $1000{ }^{\circ} \mathrm{C}$
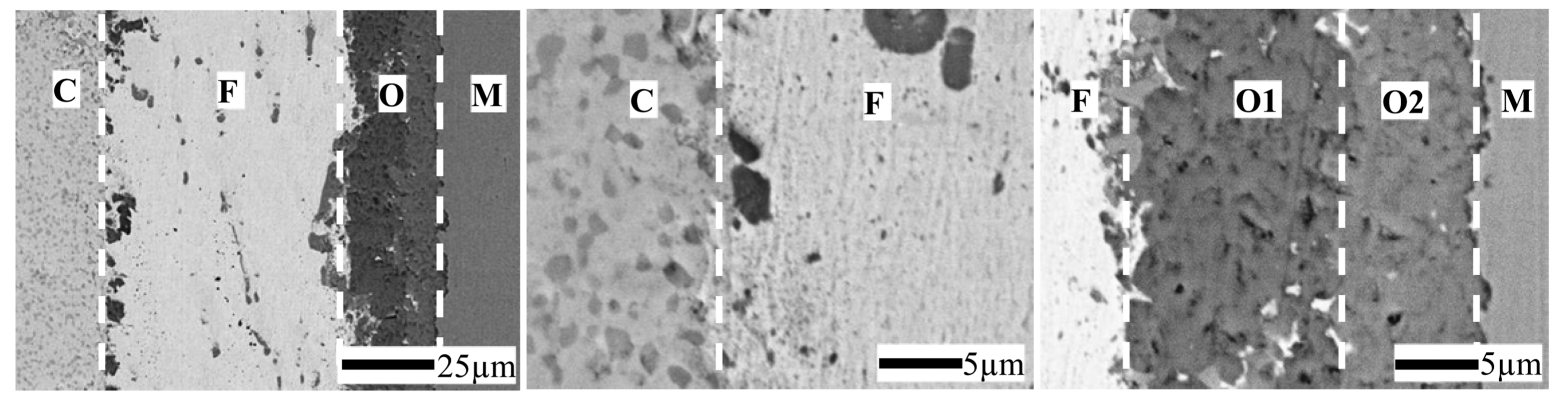

(b) $1050{ }^{\circ} \mathrm{C}$
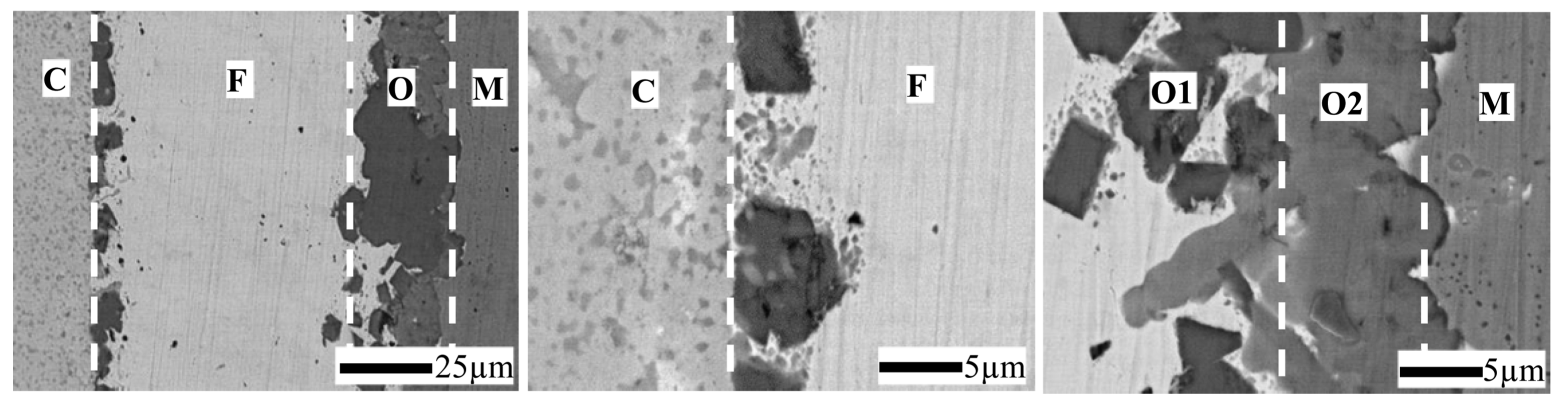

(c) $1100{ }^{\circ} \mathrm{C}$
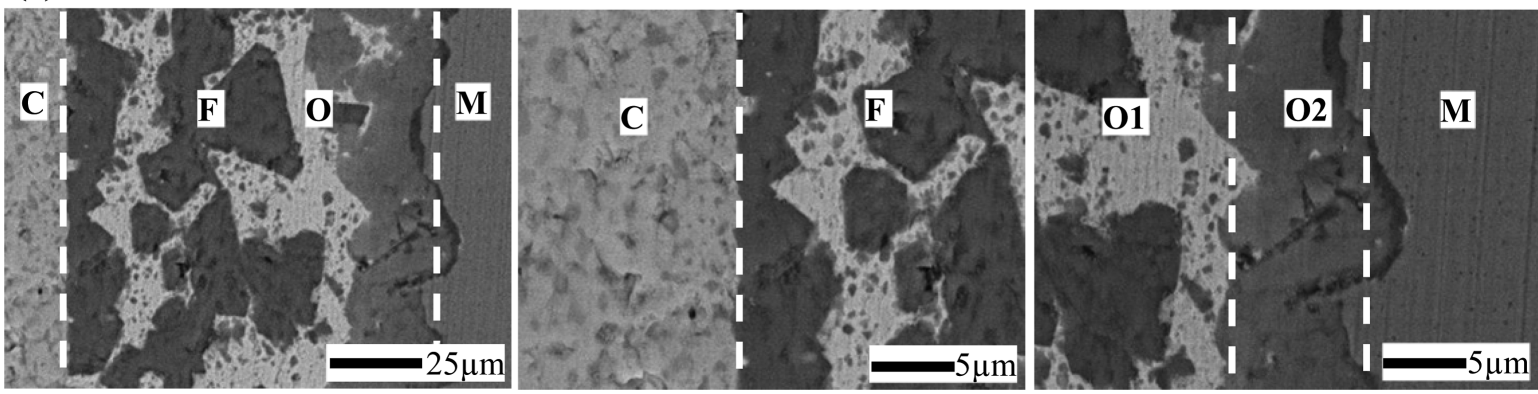

Fig. 1. SEM micrographs of GDC-LSM/Crofer 22 APU joints brazed at (a) 1000, (b) 1050 , and (c) $1100^{\circ} \mathrm{C}$ for 30 minutes. (Fig. 1 (b) Reprinted from Ref. [9], copyright with permission from Springer Nature). 
achieved. This may be attributed to two main factors: 1) adequate wetting behavior of the $\mathrm{Ag}-\mathrm{CuO}$ filler, possessing low contact angles of $30.5^{\circ}$ and $20.1^{\circ}$ for ceramic and metal alloys, respectively; $\left.{ }^{9}\right)$ 2) reduced generation of thermal residual stress during cooling from brazing temperatures, owing to ceramic, filler and metal alloys having nearly comparable coefficient of thermal expansion values of $\sim 12.7,19$ and $11.5 \times 10^{-6} \mathrm{~K}^{-1}$, respectively. ${ }^{7,9)}$

The microstructure shown in Fig. 1(a) for $1000^{\circ} \mathrm{C}$ is similar to the microstructure observed in the case of GDCLSCF/Crofer 22 APU and GDC-LSM/Crofer 22 APU joints brazed at $1050^{\circ} \mathrm{C} .^{7,9)}$ For easy comparison, the microstructure of GDC-LSM/Crofer 22 APU joints published by our group elsewhere, ${ }^{9)}$ is presented in Fig. 1(b). Four distinct regions can be clearly observed in the joints: GDC-LSM as ceramic (C), Ag-10 wt\% of $\mathrm{CuO}$ braze filler (F), oxide layer (O), and Crofer 22 APU as metal alloy (M). Fig. 1(a) and (b) reveal that the thickness of the brazed zone between the ceramic and metal alloy was approximately 60-70 $\mu \mathrm{m}$. There was no reaction zone detectable at the $\mathrm{C} / \mathrm{F}$ interfaces, revealing only a few precipitated $\mathrm{CuO}$ particles, as shown in the magnified images. $\mathrm{CuO}$ did not react with the ceramic and it tended to nucleate at the interface during cooling. On the other hand, an oxide layer was formed between the F/M interfaces with a thickness of about $20-25 \mu \mathrm{m}$. The oxide layer was composed mainly of $\mathrm{Fe}, \mathrm{Cr}$ and $\mathrm{Cu}$, as evidenced from elemental analysis using EDS. ${ }^{9)}$ The presence of $\mathrm{Cu}$ in the oxide layer suggests that the diffusion of $\mathrm{Cu}$ took place from the brazing zone to the oxide layer. According to the literature, $\mathrm{Cr}_{2} \mathrm{O}_{3}$ tends to form easily on the surface of the Crofer 22 APU due to the outward diffusion of $\mathrm{Cr}$ at the brazing temperatures. ${ }^{25,26)}$ In addition, $\mathrm{MnCr}_{2} \mathrm{O}_{4}, \mathrm{CuCr}_{2} \mathrm{O}_{4}$ and $\mathrm{FeCr}_{2} \mathrm{O}_{4}$ spinel oxides are then formed by a reaction between $\mathrm{Cr}_{2} \mathrm{O}_{3}$ and $\mathrm{Mn}_{3} \mathrm{O}_{4}, \mathrm{CuO}$ and $\mathrm{Fe}_{2} \mathrm{O}_{3}$, respectively. Moreover, separation of oxide layers also takes place. The darker oxide phase $\left(\mathrm{O}_{1}\right)$ corresponds to the spinel oxides formed, whereas the brighter oxide phase $\left(\mathrm{O}_{2}\right)$ corresponds to the $\mathrm{Fe}_{2} \mathrm{O}_{3}$ phase.

Figure 1 shows that by increasing the brazing temperature from 1000 to $1050^{\circ} \mathrm{C}$, two main changes can be observed: 1) grain growth of spinel oxides takes place and diffuses towards the filler and ceramic zones; 2) the microstructure of the oxide layer at the F/M interface becomes more rigid, while some pores can be seen in the oxide layer of joints brazed at $1000^{\circ} \mathrm{C}$. However, by further increasing brazing temperature to $1100^{\circ} \mathrm{C}$, a completely different morphology of the interfacial microstructure was observed, as shown in Fig. 1(c). The braze filler and oxide layer regions are completely mixed each other. More oxide layer is formed due to higher temperatures and it is difficult to distinguish filler and oxide regions.

To further explore this, studies were carried out on the joints brazed at $1050^{\circ} \mathrm{C}$, with varying holding times, as the joints show relatively rigid microstructures at both interfaces (as evidenced from Fig. 1). Fig. 2 compares the crosssectional SEM micrographs of GDC-LSM/Crofer 22 APU joints brazed for different times of 10 and 60 minutes at a fixed temperature of $1050^{\circ} \mathrm{C}$. It can be seen from Fig. 2 that the overall microstructures, including ceramic/filler and filler/metal alloy interfaces, are almost identical. The main difference between them is that with increasing holding time, more of the oxide layer is diffused towards the filler and ceramic regions.

Shear strengths of all joints are also presented in Table 1.

(a) $10 \mathrm{~min}$
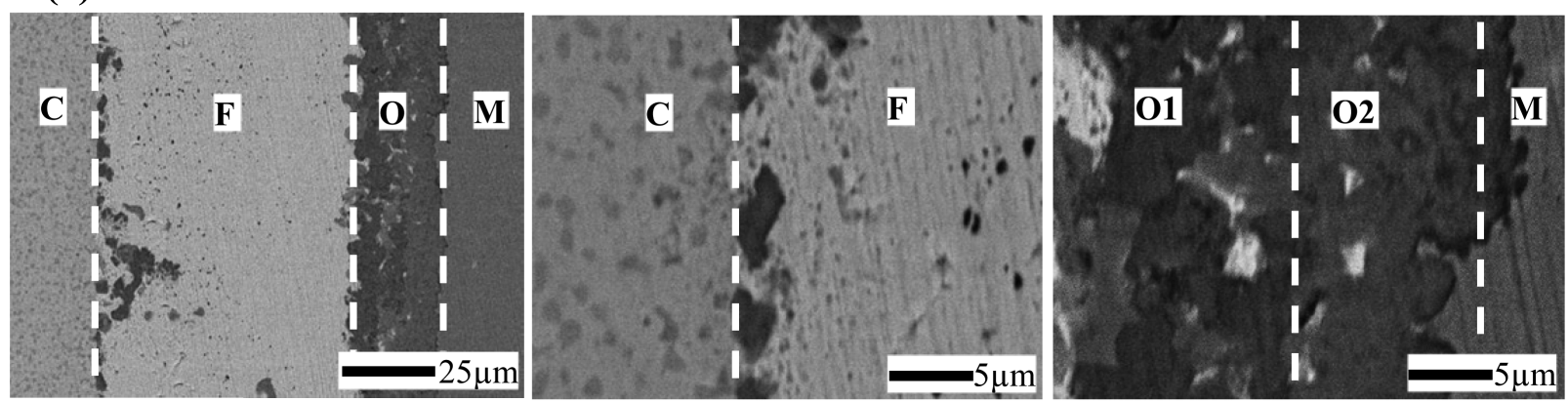

(b) $60 \mathrm{~min}$
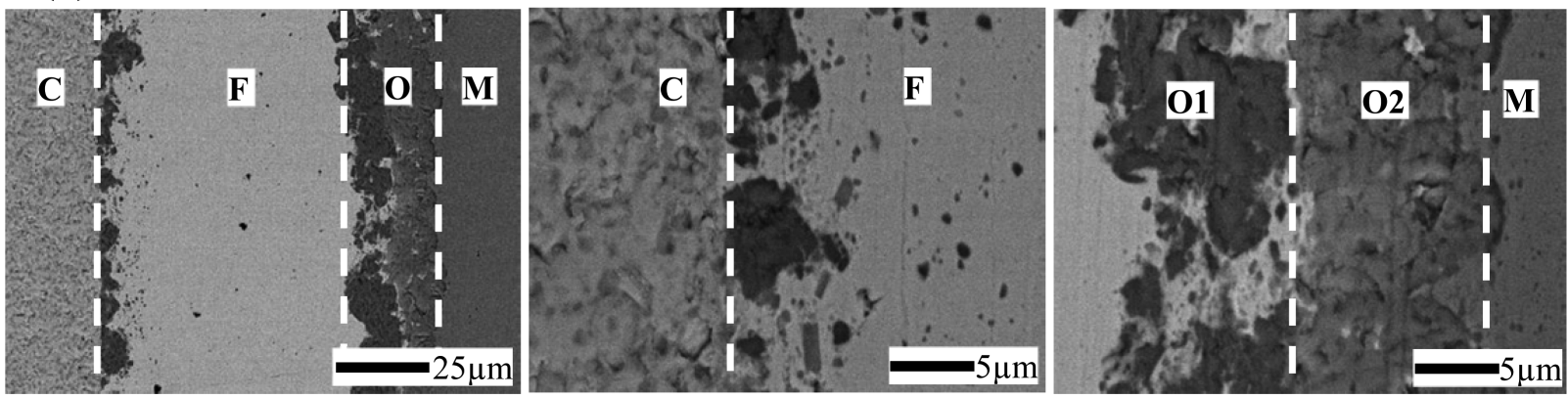

Fig. 2. SEM micrographs of GDC-LSM/Crofer $22 \mathrm{APU}$ joints brazed for (a) 10 and (b) 60 minutes at $1050^{\circ} \mathrm{C}$. 

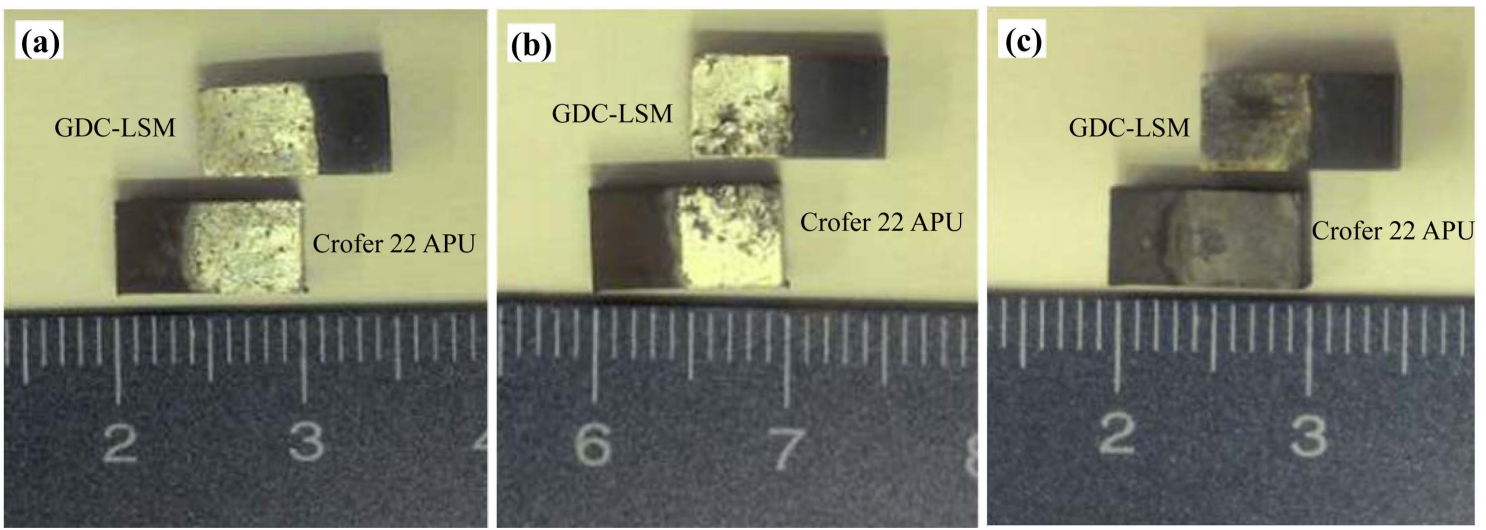

Fig. 3. Digital camera images of fractured surfaces after shear strength tests for joints brazed at temperatures of (a) 1000, (b) 1050 , and (c) $1100^{\circ} \mathrm{C}$ for 30 minutes.
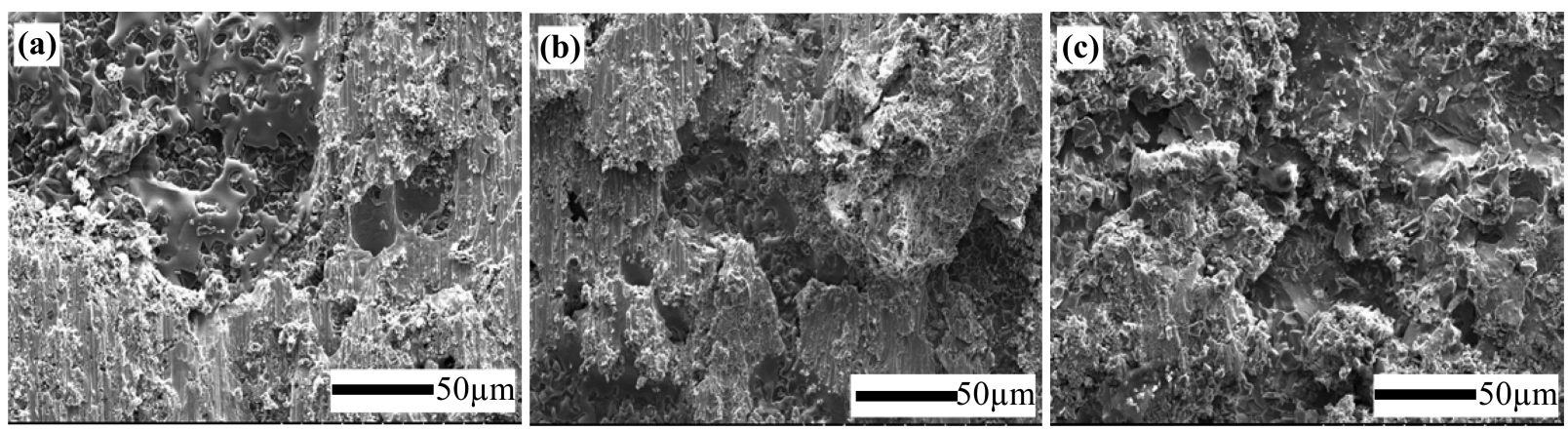

Fig. 4. Typical fractographic SEM micrographs (ceramic surface) after cohesive fracture for joints brazed for (a) 10, (b) 30, and (c) 30 minutes at a brazing temperature of $1050^{\circ} \mathrm{C}$.

It can be seen that as the brazing temperature increases from $1000^{\circ} \mathrm{C}$ to $1050^{\circ} \mathrm{C}$, shear strength decreases marginally from $91 \pm 8$ to $89 \pm 9 \mathrm{MPa}$. Increasing temperature further to $1100{ }^{\circ} \mathrm{C}$, shear strength decreases drastically to $18 \pm 5 \mathrm{MPa}$. On the other hand, if the holding time is increased from 10 to 60 minutes, shear strength decreases continuously from $100 \pm 6$ to $53 \pm 8 \mathrm{MPa}$. Superior shear strength $(100 \pm 6 \mathrm{MPa})$ can be observed at brazing conditions of $1050^{\circ} \mathrm{C}$ for $10 \mathrm{~min}$ utes. These results indicate that increasing brazing temperature and holding time decreases the shear strength values. This may be attributed to the increasing oxide layer (Figs. 1 and 2). However, higher brazing temperature has a more adverse effect on shear strength than a longer holding time. With increasing brazing temperature, additional formation of the oxide layer takes place at the filler/metal alloy interface and it diffuses more rapidly towards the ceramic filler. Moreover, the width of the oxide layer increases, while the width of residual brazing $\mathrm{Ag}-\mathrm{CuO}$ filler gradually decreases. The interfacial microstructure of the brazed joints varied evidently with an increase in brazing temperature, which may have had a pivotal role in affecting the mechanical properties of the joints.

Figure 3 shows the digital camera images of fractured surfaces after shear strength tests of joints brazed at temperatures of 1000,1050 , and $1100^{\circ} \mathrm{C}$, for 30 minutes. Fracturing occurred mainly at the joining interfaces and this indicates a cohesive failure. Fig. 4 shows typical fractographic SEM micrographs (ceramic surface) after cohesive fracture of joints brazed for 10,30 , and 60 minutes at a brazing temperature of $1050^{\circ} \mathrm{C}$. A uniformly distributed and densely packed braze filler can be observed.

\section{Summary}

The effects of brazing temperatures and holding times on the interfacial microstructures and shear strengths were examined for GDC-LSM/Crofer 22 APU joints. Compact joining was achieved for all joints without the presence of cracks. The results showed that with increasing brazing temperatures and holding times, joint microstructure was clearly changed and shear strengths were decreased. Particularly, the use of brazing temperatures of $1100^{\circ} \mathrm{C}$ for 30 minutes is detrimental to shear strengths. Furthermore, the use of longer holding times at $1050^{\circ} \mathrm{C}$ is not necessary for brazing. Finally, this study suggests the use of optimal brazing condition of $1050^{\circ} \mathrm{C}$ for 10 minutes, as this offers the highest shear strength of $100 \pm 6 \mathrm{MPa}$.

\section{Acknowledgments}

This work was supported by the Korea Institute of Energy Research through research and development program num- 
ber B8-2415.

\section{REFERENCES}

1. J. S. Hardy, J. Y. Kim, and K. S. Weil, "Joining Mixed Conducting Oxides Using an Air-Fired Electrically Conductive Braze," J. Electrochem. Soc., 151 [8] J43-9 (2004).

2. J. Y. Kim, J. S. Hardy, and K. S. Weil, "Effects of $\mathrm{CuO}$ Content on the Wetting Behavior and Mechanical Properties of a $\mathrm{Ag}-\mathrm{CuO}$ Braze for Ceramic Joining," J. Am. Ceram. Soc., 88 [9] 2521-27 (2005).

3. K. S. Weil, C. A. Coyle, J. T. Darsell, G. G. Xia, and J. S. Hardy, "Effects of Thermal Cycling and Thermal Aging on the Hermeticity and Strength of Silver-Copper Oxide AirBrazed Seals," J. Power Sources, 152 97-104 (2005).

4. J. Y. Kim, J. S. Hardy, and K. S. Weil, "Dual-Atmosphere Tolerance of Ag-CuO-Based Air Braze," Int. J. Hydrogen Energy, 32 [16] 3655-63 (2007).

5. J. Y. Kim and K. S. Weil, "Effects of Brazing Time and Temperature on the Microstructure and Mechanical Properties of Aluminum Air Brazed Joints," J. Am. Ceram. Soc., 90 [12] 3830-37 (2007).

6. H. Chen, L. Li, R. Kemps, B. Michielsen, M. Jacobs, F. Snijkers, and V. Middelkoop, "Reactive Air Brazing for Sealing Mixed Ionic Electronic Conducting Hollow Fibre Membranes," Acta Mater., 88 74-82 (2015).

7. K. Raju, Muksin, S. Kim, K. Song, J. H. Yu, and D. H. Yoon, "Joining of Metal-Ceramic Using Reactive Air Brazing for Oxygen Transport Membrane Applications," Mater. Des., 109 233-41 (2016).

8. K. Raju, Muksin, and D. H. Yoon, "Reactive Air Brazing of GDC-LSCF Ceramics Using Ag-10 wt\% CuO Paste for Oxygen Transport Membrane Applications," Ceram. Int., 42 [14] 16392-95 (2016).

9. M. F. R. Wahid, D. H. Yoon, K. Raju, S. Kim, K. Song, and J. H. Yu, "Interfacial Microstructure and Shear Strength of Reactive Air Brazed Oxygen Transport Membrane Ceramic-Metal Alloy Joints," Met. Mater. Int., 24 [1] 15769 (2018).

10. M. D. Kim, M. F. R. Wahid, K. Raju, S. Kim, J. H. Yu, C. D. Park, and D. H. Yoon, "Efficacy of Ag-CuO Filler Tape for the Reactive Air Brazing of Ceramic-Metal Joints," $J$. Korean Ceram. Soc., 55 [5] 492-7 (2018).

11. A. Ibrahim and F. Hasan, "Influence of Processing Parameters on the Strength of Air Brazed Alumina Joints Using Aluminum Interlayer," J. Mater. Sci. Technol., 27 [7] 641-46 (2011).

12. M. Khakian, S. Nategh, and S. Mirdamadi, "Effect of Bonding Time on the Microstructure and Isothermal Solidification Completion During Transient Liquid Phase Bonding of Dissimilar Nickel-based Superalloys IN738LC and Nimonic 75," J. Alloys Compd., 653 386-94 (2015).

13. I. Goto, S. Aso, and K. I. Oguchi, "Effect of Joining Conditions on the Shear Strength of Barium Titanate Joint Brazed with Molten Aluminum," Mater. Trans., 58 [8] 1175-80 (2017).

14. Q. Wang, Y. Fu, Q. Lang, J. Yan, and S. Chen, "Microstructure and Mechanical Properties of Magnesium Alloys Joints with Ag-Cu Interlayer by Ultrasonic- induced Transient Liquid Phase Bonding in Air For Structure Lightweight Design," Mater. Lett., 237 37-40 (2019).

15. A. Kaletsch, A. Bezold, E. M. Pfaff, and C. Brockmann, "Effects of Copper Oxide Content in $\mathrm{AgCuO}$ Braze Alloy on Microstructure and Mechanical Properties of Reactive Air-Brazed $\mathrm{Ba}_{0.5} \mathrm{Sr}_{0.5} \mathrm{Co}_{0.8} \mathrm{Fe}_{0.2} \mathrm{O}_{3-8}$ (BSCF)," J. Ceram. Sci. Technol., 3 [2] 95-104 (2012).

16. K. Bobzin, M. Ote, S. Wiesner, A. Kaletsch, and C. Broeckmann, Characterization of Reactive Air Brazed Ceramic/Metal Joints with Unadapted Thermal Expansion Behavior," Adv. Eng. Mater., 16 [12] 1490-97 (2014).

17. E. Skiera, J. Brandenberg, C. Li, T. Koppitz, T. Beck, L. Singheiser, and B. Kuhn, "Mechanical Properties of Reactive Air Brazed (RAB) Metal/Ceramic Joints. Part 2: Tailored Microstructure for Thermal Cycling Resistance," Adv. Eng. Mater., 16 [12] 1423-29 (2014).

18. E. Prevost, A. J. D. Marco, B. M. Michael, V. V. Joshi, A. Meier, J. W. Hoffman, and W. J. Walker, "Microstructural Development and Mechanical Properties for Reactive Air Brazing of ZTA to Ni Alloys Using Ag-CuO Braze Alloys," Adv. Eng. Mater., 16 [12] 1448-55 (2014) .

19. K. M. Erskine, A. M. Meier, V. V. Joshi, and S. M. Pilgrim, "The Effect of Braze Interlayer Thickness on the Mechanical Strength of Alumina Brazed with $\mathrm{Ag}-\mathrm{CuO}$ Braze Alloys," Adv. Eng. Mater., 16 [12] 1442-47 (2014) .

20. J. Cao, X. Si, W. Li, X. Song, and J. Feng, "Reactive Air Brazing of YSZ-Electrolyte and $\mathrm{Al}_{2} \mathrm{O}_{3}$-Substrate for Gas Sensor Sealing: Interfacial Microstructure and Mechanical Properties," Int. J. Hydrogen Energy, 42 [15] 10683-94 (2017)

21. J. H. Joo, K. S. Yun, J. H. Kim, Y. Lee, J. Jung, C. Y. Yoo, and J. H. Yu, "Substantial Oxygen Flux in Dual-Phase Membrane of Ceria and Pure Electronic Conductor by Tailoring the Surface," ACS Appl. Mater. Interfaces, 7 [27] 14699-707 (2015).

22. B. T. Na, J. H. Park, J. H. Park, J. H. Yu, and J. H. Joo, "Elucidation of the Oxygen Surface Kinetics in a Coated Dual-Phase Membrane for Enhancing Oxygen Permeation Flux," ACS Appl. Mater. Interfaces, 9 [23] 19917-24 (2017).

23. B. Kuhn, F. J. Wetzel, J. Malzbender, R. W. Steinbrech, and L. Singheiser, "Mechanical Performance of ReactiveAir-Brazed (RAB) Ceramic/Metal Joints for Solid Oxide Fuel Cells at Ambient Temperature," J. Power Sources, 193 [1] 199-202 (2009).

24. S. Kim, J. H. Joo, S. D. Kim, and S. K. Woo, "Evaluation of $\mathrm{CaO}-\mathrm{Al}_{2} \mathrm{O}_{3}$ Adhesive Bonding Properties for $\beta^{\prime \prime}-\mathrm{Al}_{2} \mathrm{O}_{3}$ Solid Electrolyte Sealing for Alkali Metal Thermal Electric Converter," Ceram. Int., 39 [8] 9223-27 (2013).

25. N. J. Magdefrau, L. Chen, E. Y. Sun, AND M. Aindow, "Effects of Alloy Heat Treatment on Oxidation Kinetics and Scale Morphology for Crofer 22 APU," J. Power Sources, 241 756-67 (2013).

26. K. Przybylski, T. Brylewski, E. Durda, R. Gawel, and A. Kruk, "Oxidation Properties of the Crofer 22 APU steel Coated With $\mathrm{La}_{0.6} \mathrm{Sr}_{0.4} \mathrm{Co}_{0.2} \mathrm{Fe}_{0.8} \mathrm{O}_{3}$ for IT-SOFC Interconnect Applications," J. Therm. Anal. Calorim., 116 [2] 82534 (2014). 